\title{
E-GOVERNMENT, GOVERNANCE AND CORRUPTION IN ASIAN COUNTRIES
}

\author{
Imelda Suardi \\ Swiss German University, Tangerang, Indonesia
}

\section{Article Information}

Received: 18 June 2021

Accepted: 16 September 2021

Published: 30 September 2021

DOI: $10.33555 / \mathrm{embm} . v 8 \mathrm{i} 2.180$

\section{Corresponding Author:}

Imelda Suardi

Jakarta, Indonesia

Email: isuardi@yahoo.com

ISSN 2338-8854

eISSN 2620-9918

\begin{abstract}
In developing countries, the implementation of e-government is at greater risk of failure when the corruption is still high. This paper examines the effect of e-government on the level of corruption in 47 developing countries in Asia using E-Government Development Index which is divided into components of online service, human capital, telecommunication infrastructure and $e$ participation. This paper also places the role of governance in government to moderate the relationship between e-government and perceptions of corruption. The result shows that implementation of e-government and governance has increased the perception of corruption with telecommunications infrastructure has the most significant effect.

Keywords: Corruption Perception Index, EGD, E-Government, Governance, Transparency
\end{abstract}




\section{Introduction}

\subsection{Background}

The use of Information Communication and Technology (ICT) in the public sector, accompanied by the e-business revolution, is said to expand the depth and level of transparency at a reduced cost and to potentially generate new opportunities for participation and accountability (Bertot, 2010). In addition to the increase in equitable and sustainable access to public information to government, ICT also increases accountability and trust in government (Pina, 2007), minimizing administrative errors and the amount of corruption. Good governance is encouraged through the initiative of government agencies and departments to use ICTs, reinforce established relationships and create new partnerships in society, known as eGovernment initiatives (Ndou, 2004). The emergence of e-government programs helps to address governance problems by enhancing the efficiency and effectiveness of public services as well as democratic legitimacy from the government (Cordella, 2017).

E-government initiation appears to provide fast and easy access to public information, thereby increasing public transparency and government performance (Geiller, 2019). With the use of ICTs, the governance mechanism can be improved by offering open dialogue tools and constructive public debate (Choi, 2016). The benefits of egovernment are increasingly being felt in many countries. Progress has been made by most countries in the delivery of online services and in the implementation of egovernment initiatives and ICT applications, enabling them to enhance public sector performance and streamline governance processes to promote sustainable growth, as stated by United Nations in 2012. In addition, to make public information more available, e-government can reduce corruption by preventing pricefixing, reducing bribery opportunities and providing opportunities for whistleblowers to expose corruption (Bertot, 2010). As reported by Satyanarayana (n.d.), more effective services for people \& industries are the advantages of e-government for the government, better government image, reduced costs, better targeting of benefits and corruption control.

Transparency has recently become more important because the ICTs used in supporting e-government initiatives have become increasingly viable for disseminating information. With the growth of the internet, e-government has made great progress which is now a very important instrument for governments in their interactions with people and industries (Susha, 2015). According to (Krause, 2014), the evolution of e-government must improve the quality of the government's web, facilitate government relations with stakeholders and increase transparency. Transparency promotes clarity by enabling members of the media, regulatory bodies and other stakeholders to identify, process and reuse meaningful information from government data.

The effect of internet use on corruption has been examined by many empirical studies. The findings indicate that, by using a different method, a high level of internet usage is correlated with a low level of corruption (Starke, 2016). In particular, a number of studies on the role of egovernment in curbing corruption have been conducted. Research of (Srivastava, 2016) shows that the level of e-government development in a country has negative relationship with the level of corruption in three forms which are political, legal, and media institution. Report of (Krishnan, 2013) indicates that the maturity of egovernment, through the mediating influence of corruption, affects economic growth and environmental degradation. Meanwhile (Nam, 2018) demonstrates that the maturity of e-government leads to eradicating corruption, and the anticorruption impact of e-government is 
controlled by the national culture which are the power of authority, individualism, masculinity, and uncertainty avoidance.

\subsection{Problem}

While developing countries expect positive effects of e-government comparable to those developed countries (Choi, 2016), egovernment initiatives in developing countries have greater impact. The publication found that in developing countries, between $60 \%$ and $85 \%$ of egovernment implementations showed total or partial failure (Mates, 2013). In the growth of developing countries, the challenges, leadership, plan and management of the implementation of egovernment play an important role. Until now, e-government projects have appeared to be an extension of the current model of management governance. As a result, the influence of e-government initiatives, while recognized as an advantage, is still limited. (Osman, 2014).

Academics and policy-makers have reported the impact of ICT on corruption experienced by a country. Research of (LIO, 2011) shows that the influence of ICT adoption on corruption reduction is statistically significant but not overly important. According to the 2018 Corruption Perception Index, more than two-thirds of countries have rating below 50 with an overall average score of 43 . This reveals that continuing inability of most countries to significantly control corruption leads to the worldwide political crisis. Despite exceptions and some progress in some countries, most countries fail to make serious inroads into corruption (International, 2018). This reveals the continuing failure of most countries to significantly control corruption. Current literature still underlines the great potential, impacts and outcomes of ICT primarily based on the private sectors (Ndou, 2004). As it continues to be left behind in the process of technology adoption and business re-creation, the public sector has been sidelined. Lack of research focuses on e-government mechanism, so it is important to establish an assessment system for electronic government implementation in developing countries specifically (Yildiz, 2007).

In developing countries, the capacity of egovernment is still very large, although not highly exploited. Various human, organizational and technical variables, related problems in these nations, require oriented and effective approaches to research. Several e-government programs, however, have advanced. The advantages of ICT can be successfully used and used by governments in developing countries, but egovernment progress involves some needs and barriers. E-government adaptive challenges go further than technology because it involves organizational structure, expertise, leadership and transformation of public-private partnerships (Allen, 2001).

\subsection{Objective}

The objective of this paper is to examine the impact of e-government implementation and its influence on the level of corruption in developing countries, especially in Asia. This study also examines the effect of governance on e-government relations and the level of corruption. The reasons to select Asian countries are not only the most populous region but also the region with the largest landfall. Based on e-government surveys issued by the UN (United Nation, 2018), e-government advancement trends vary widely across nations in the region. The success of Asia in e-government enhancement from 2016 to 2018 is an ongoing challenge to the role of America as the second-best performing continent. In fighting for corruption, the Asia Pacific Region is stagnant. Given the prevalence of weak political institutions and the absence of law enforcement systems that lead to higher levels of corruption, the lack of progress is not a surprise. Nevertheless, this region is very complex in its approach to anti-corruption. In different countries, 
massive public mobilization against corruption and voter participation resulted in new governments and anti-corruption reforms. Moreover, with little improvement in combating corruption, Central Asia is the second-lowest scoring region in the index. Lack of political will, poor institutions and scarce political rights create an atmosphere in which, with little opposition, major forms of corruption flourish. The battle against corruption in the Middle East remains grim. It is not surprising that corruption remains high in a region where civil liberties remain under authoritarian state control and the social contract between the government and its people have been severed for decades (United Nation, 2018).

\subsection{Scope and Limitations}

This paper uses the control variable of developing countries in Asia. A United Nations e-government survey found there is a positive relation between level of income and e-government ranking. In general, most middle-income countries have higher scores in e-government development index. This pattern is consistent with the previous finding results. For all e-government indices, high-income countries advance faster and perform well with low score gaps. For developing countries with low and middle income, the increase in the score of infrastructure expansion and the quality of online services over the past four years is quite encouraging leading to a comprehensive improvement in e-government development (United Nation, 2018). This paper uses the e-government development index issued by the UN and divides it into online service, human capital, telecommunication infrastructure and e-participation categories. EGDI itself consists of online service components, human capital and telecommunication infrastructure (United Nation, 2018). Therefore, this paper examines the total EGDI and its components separately to see the effect of each component of egovernment and avoid bias. This paper empirically examines the relationship of egovernment implementation which is divided into several components with the perception of corruption because it is likely to produce different effects. In addition, this research places the role of governance, in this case, government effectiveness as a moderating variable to strengthen the influence of e-government and the perception of corruption. The results of this paper will contribute to countries in Asia that have implemented e-government, specifically regarding their effects on the perception of corruption. So far, there have not been many studies on related topics that focus on the application of e-government in developing Asian countries that need attention.

\section{Theory and Hypothesis}

\subsection{E-government}

E-government is the transformation of government to provide efficient, convenient and transparent services to the citizens and businesses through ICT (Satyanarayana, n.d.) or the use of ICT to radically transform how government delivers services to citizens (Ryan, n.d.).

As indicated by (United Nation, 2018) the E-Government Development Index (EGDI) is a weighted average score of the three most relevant components of e-government, in particular the scope and quality of online services as indicated by the Online Service Index, the development of Telecommunications infrastructure which is assessed by the Telecommunications Infrastructure Index and inherent human capital demonstrated by the Human Capital Index.

\subsection{E-participation}

E-participation, involves the extension and transformation of participation in societal democratic and consultative processes mediated by ICT primarily the Internet (Saebo, 2008). E-participation aims at achieving many goals such as using available technologies to support active citizenship, enabling broader participation for reaching a wider audience, and enabling 
more informed citizens' contributions through providing accessible and understandable information to target audience (Sobaci, 2010).

As stated by the United Nation in 2013, Eparticipation is defined as the way to involve citizens through ICT in strategy, decision making, design and delivery of services to make citizens participatory, inclusive and deliberative. For each of the above criteria, the overview assessed the accessibility of e-participation tools on the national government portal. It was reported in the 2018 Survey that more governments are encouraging people and industries to cooperate by contributing thoughts and giving feedback.

\subsection{Online Service}

Online service is an indicator that measures the evolution of e-government services in terms of availability, quality, connectivity and diversity of channels and the use by the public of these services (UAE Vision, 2021).

The Online Services Index is a measure that quantifies the use of ICTs at the national level to provide public services. This depends on a comprehensive survey that evaluates the technological features of national websites and e-government procedures that are generally applied by certain sectors in providing services. Member countries have national portals and back-end systems that automate key task management, increase public service availability, promote transparency and accountability. Different government sectors continue to embrace and use technologies to digitalize information collection, storage, review and sharing (United Nation, 2018).

\subsection{Telecommunications Infrastructure}

The Telecommunications Infrastructure is a composite indicator that measures the countries' Telecommunication infrastructure readiness to adopt the opportunities offered by ICT as to enhance their competitiveness (UAE Vision, 2021). The Index for Telecommunication Infrastructure used average combination of five indicators which are estimated internet users, number of fixed telephone lines, number of cellular subscribers, number of wireless broadband subscriptions and number of fixed broadband subscriptions.

\subsection{Human Capital}

Human Capital is the knowledge, skills, and health that people accumulate over their lives, a central driver of sustainable growth and poverty reduction. More human capital is associated with higher earnings for people, higher income for countries, and stronger cohesion in societies (World Bank, 2020). The Human Capital Index (HCI) is an international metric that benchmarks the key components of human capital across economies. It was launched in 2018 as part of the Human Capital Project, a global effort to accelerate progress toward a world where all children can achieve their full potential. The Index consists of four components which are namely adult literacy level, primary, secondary and tertiary enrolment ratios, expected years of schooling and average years of schooling.

\subsection{Government Governance}

Government governance consists of customs and institutions authorized by a country. This incorporates the mechanism by which government is elected, supervised and replaced, government's ability to devise and execute sound policies efficiently and appreciation of individuals towards institutions that regulate their economic and social interactions. World Governance Index from the World Bank reports indicators of state and regional governance into several dimensions of governance namely voice and accountability, political stability and no violence, government effectiveness, quality of regulations, rule of law and corruption control (World Bank, 2019). 


\subsection{Corruption Perception}

Corruption defined as the abuse of entrusted power for private gain. Corruption erodes trust, weakens democracy, hampers economic development and further exacerbates inequality, poverty, social division and the environmental crisis. Exposing corruption and holding the corrupt to account can only happen if we understand the way corruption works and the systems that enable it (Transparency International, 2021).

The Corruption Perception Index, released in 1995, is Transparency International's flagship research product and has become a leading worldwide indicator of public sector corruption. In 2018, the CPI used 13 evaluation surveys of experts and executives on several corrupt behaviors in the public sector. Some sources look at the tools available in a country to deter corruption, such as government's capacity to enforce integrity, effective prosecution of corrupt officials, unnecessary bureaucratic burdens, laws on financial disclosure, conflicts of interest prevention, access to information and legal security for reporter, journalist and investigator (International, 2018).

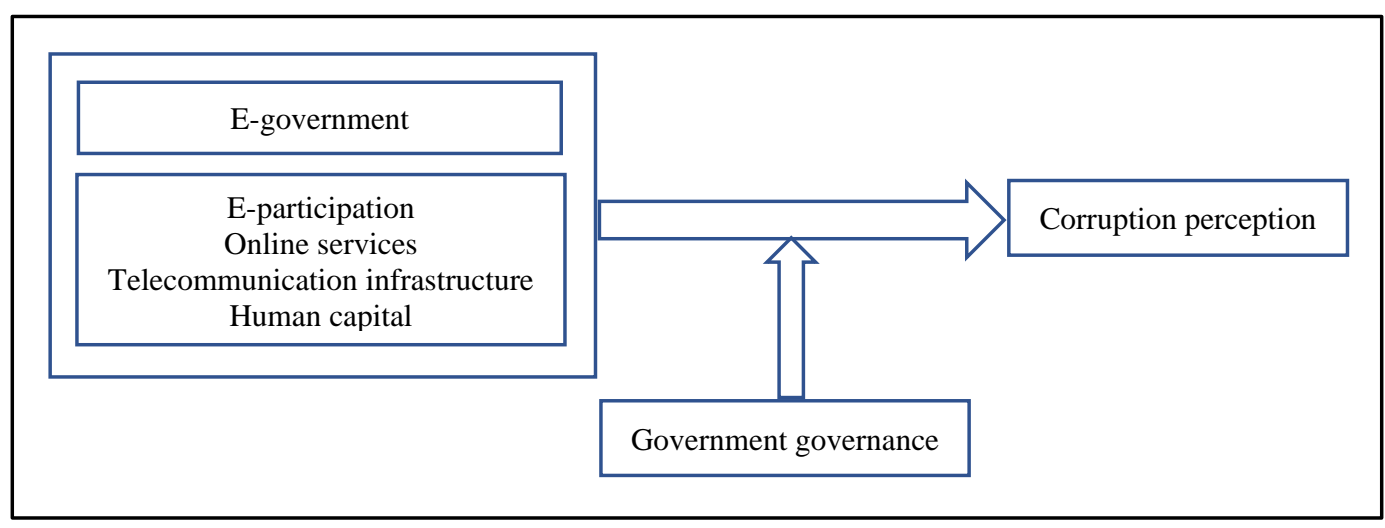

Figure 1. Theoretical framework

E-government implementation has the advantage of bridging the flow of information from both the government and citizens who operate e-government platforms or applications. On the other hand, how a country views corruption will also affect. The higher implementation of egovernment shows the higher trust and transparency so that the perception of citizens in the fight against corruption in their country will increase.

Hypothesis 1: E-government has a positive effect on perceptions of corruption.

Online participation and online public services make it easier and faster for people to access and interact with government. With easy and fast communication facilities, the flow of information will be smoother, so that the perception of citizens in anticipating corruption can increase. Telecommunications infrastructure is a basic requirement in implementing egovernment. Large and comprehensive telecommunications infrastructure investment shows the government's commitment to implement e-government. If telecommunications infrastructure is weak, then the possibility of e-government in that country will not be strong. A strong telecommunications infrastructure will show the government's efforts are moving towards an era of openness so that citizens' perceptions of the government in anticipating corruption can increase. The quality of human resources is very influential to the success of e-government. The better the quality of Human Resources such as education, employment and skills will 
facilitate the use of electronic government. Quality human resources will be better in assessing the perception of corruption in the country.

Hypothesis 2: E-participation, online services, telecommunications infrastructure, human capital have positive effect on perceptions of corruption.

The role of governance is believed to have a lot of impact on the governance of a country. Governance in public sector can be applied in many ways including egovernment. The success of e-government projects can be influenced by the application of good governance. Meanwhile, the implementation of effective and efficient public governance in a country is expected to reduce the amount of corruption and improve the perception of its citizens. Therefore governance is expected to strengthen e-government relations and corruption perceptions.

Hypothesis 3: Government governance reinforces the positive influence between egovernment implementation and perceptions of corruption.

Hypothesis 4: Government governance reinforces the positive influence between the implementation of e-participation, online services, telecommunications infrastructure, human capital and the perception of corruption.

\section{Methodology}

\subsection{Population and Sample Data}

The population for this research is 47 Asian countries implementing e-government during the 2016-2018 period. This research was conducted by making a regression analysis with STATA software to test and see the effect of e-government implementation on the perception of corruption. Index data is obtained from secondary data, namely through very reliable and globally valid sources of information and with very reliable survey methods.

\subsection{Methodology}

This paper uses the e-government index issued by the UN as an independent variable. E-Government Development Index is the weighted average score of the three most significant components of egovernment namely the scope and quality of online services as indicated by the Online Services Index, the status of telecommunications infrastructure development assessed through the Telecommunications Infrastructure Index and inherent human capital assessed through the Human Capital Index. Each of these indices is a composite measure which can be independently derived and evaluated. The value of each component index is then normalized to be in the range between 0 to 1 . The total EGDI is derived by taking the average of the threeindexes. E-Government Development Index is measured from the average threedimensional score of e-government namely the Online Service Index, the Telecommunications Infrastructure Index and the Human Capital Index. The value of each component index is then normalized so that it is in the range of 0 to 1 . The next independent variable is the E-Participation Index which is measured based on e-information or online data accessibility, econsultation or online public discussion and e-decision making when citizens are engaged in the decision making process. The online service index is an independent variable measured from the technical features of national websites, e-government policies and strategies for providing services. The results are tabulated on a scale of 0 to 1 as index values, with 1 corresponding to the highest-ranked and 0 to the lowest. The Telecommunication Infrastructure Index is also an independent variable determined by the combined average of estimated internet users, the number of fixed telephone lines, cellular subscribers, wireless broadband subscriptions and fixed broadband subscriptions. Moreover, the Human Capital Index is an independent variable measured by components the level of adult literacy, enrollment ratios of 
primary, secondary and tertiary level, expected school years and average school years (United Nation, 2018).

This paper uses a corruption perception index issued by Transparency International as a dependent variable with an index score on a scale from 0 very corrupt to 100 very clean. Bribery, diversion of public funds, use of public office for personal benefit, nepotism in public services and country arrest are the indicators used in this CPI (International, 2018). Worldwide Governance Indicator which is issued by the World Bank, is used as a moderating variable. This index reports indicators of state and regional governance in several dimensions of governance. To measure governance related to e-governance, this paper focuses on the dimension of government effectiveness which measures perceptions about the quality of public services, the quality of civil services and the degree of independence from political interference, the quality of policy development and implementation and the legitimacy of government engagement to the policy (World Bank, 2019). The government effectiveness index rating varies from -2.5 for the least effective to 2.5 for the most effective. This paper also uses lower middle income as a control variable for developing countries which are categorized as having a lower middle income. The measurement used is 1 if it is lower-middle or developing countries and 0 if it is not.

Below are the research models:

$$
\begin{aligned}
& \mathrm{CPI}=\alpha+\beta 1 \text { egov }+\beta 2 \text { lowinc }+\epsilon \\
& \mathrm{CPI}=\propto+\beta 1 \text { epart }+\beta 2 \text { ols }+\beta 3 \text { ti }+\beta 4 \text { hc }++\beta 5 \text { lowinc }+\epsilon \\
& \mathrm{CPI}=\propto+\beta 1 \text { egov }+\beta 2 \text { goeff }+\beta 3 \text { egov } * \text { goeff }+\beta 4 \text { lowinc }+\epsilon \\
& \mathrm{CPI}=\propto+\beta 1 \text { epart }+\beta 2 \text { ols }+\beta 3 \text { ti }+\beta 4 \text { hc }+\beta 5 \text { goeff }+\beta 6 \text { epart } * \text { goeff }+\beta 7 \text { ols } * \\
& \text { goeff }+\beta 8 * \text { ti } * \text { goeff }+\beta 9 \text { hc } * \text { goeff }+\beta 10 \text { lowinc }+\epsilon
\end{aligned}
$$

Notes:

$\mathrm{CPI}=$ corruption perception index

Egov $=$ e-government development index

Epart $=\mathrm{e}$-participation index

Ols $=$ online service index

$\mathrm{Ti}=$ telecommunication infrastructure index

$\mathrm{Hc}=$ human capital index

Goeff $=$ government effectiveness index

Lowinc $=$ low income country

\section{Result}

Table 1 shows comparison of the average variable index from 2016 to 2018. The egovernment development index is set by the United Nation every 2 years, therefore, 2017 data is the same as 2018 data. Overall, the implementation of EGDI in Asia shows an improvement from 2016 to 2017, the same goes for index components such as online service, human capital, telecommunication infrastructure and e-participation. The corruption perception index also increased from 2016 to 2018 . However, the effectiveness of governments in Asia on average still has a minus score and has decreased slightly in 2018. 
Table 1. Average Index Comparison

\begin{tabular}{|r|l|l|l|l|l|l|l|}
\hline Period & EGOV & EPART & OLS & HC & TI & CPI & GOEFF \\
\hline 2016 & 0,5132 & 0,5182 & 0,5120 & 0,6545 & 0,3730 & 38,1915 & $-0,0870$ \\
\hline 2017 & 0,5779 & 0,6126 & 0,6216 & 0,6735 & 0,4385 & 38,6809 & $-0,0990$ \\
\hline 2018 & 0,5779 & 0,6126 & 0,6216 & 0,6735 & 0,4385 & 38,7660 & $-0,0986$ \\
\hline
\end{tabular}

The result of hypothesis 1 regression testing with Random Effect shows that the implementation of e-government in a country has a significant positive effect on the perception of corruption in that country, as stated in Table 2. The higher the egovernment development index, the higher the corruption perception index.

Table 2. Result Hypothesis 1

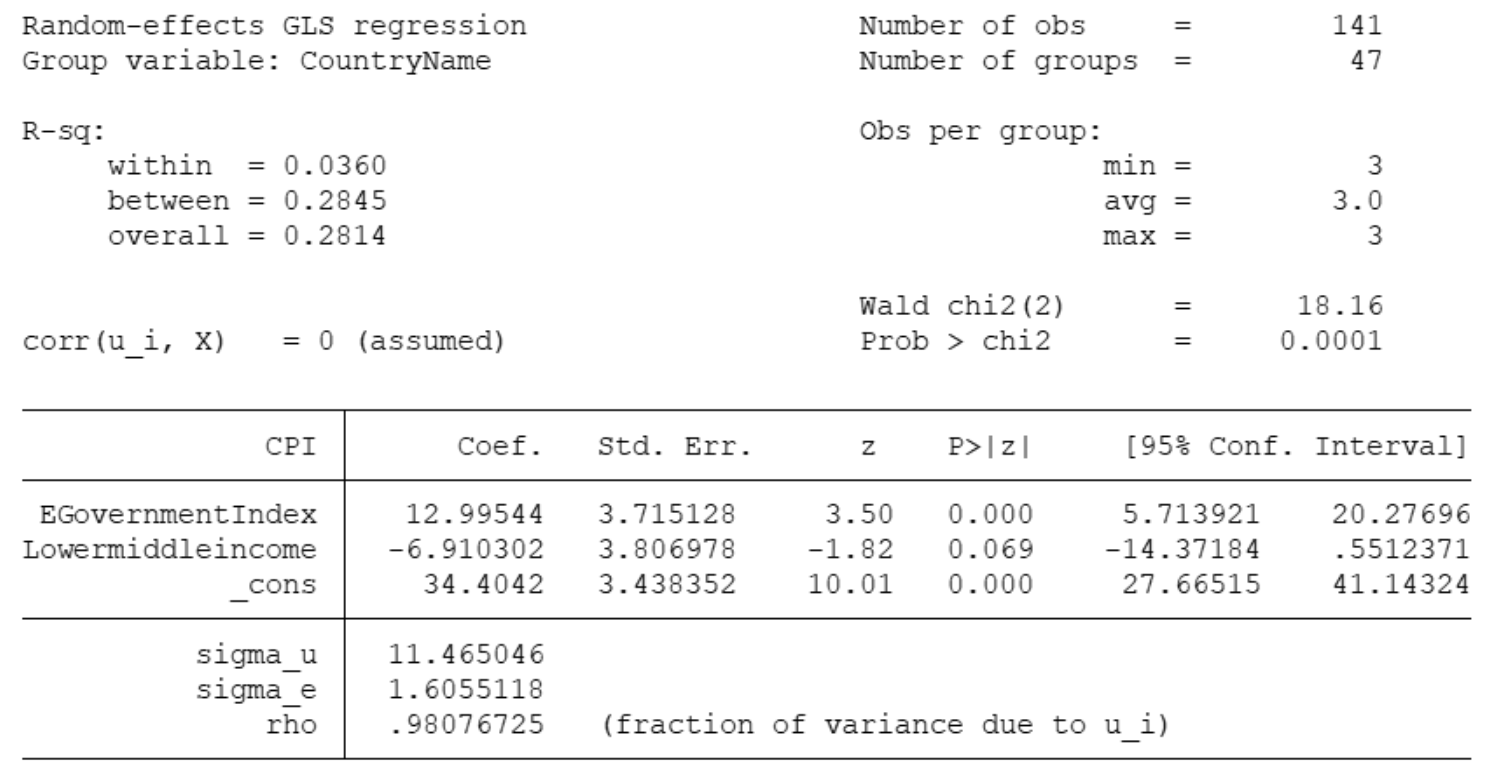

The regression results for testing hypothesis 2 find that only telecommunication infrastructures have a significant positive influence on perceptions of corruption as showed in Table 3. This means that with more frequent internet users, the number of fixed telephone lines, cellular subscribers, wireless broadband subscriptions and broadband subscriptions shows the higher use of technology and information access in the community for government services, thus increasing perceptions of corruption. While e-participation, online service and human capital have no significant effect. 
Table 3. Result Hypothesis 2

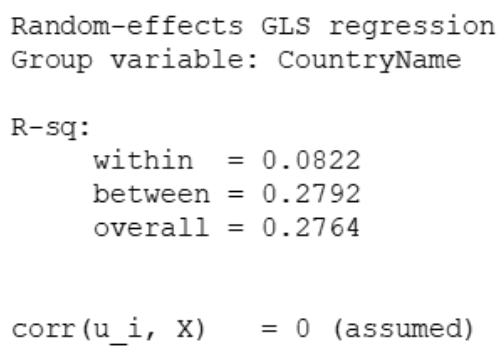

\begin{tabular}{|c|c|c|c|c|c|c|}
\hline $\mathrm{CPI}$ & Coef. & Std. Err. & $z$ & $\mathrm{P}>|\mathrm{z}|$ & [95\% Conf. & Interval] \\
\hline EParticipationIndex & .3923141 & 4.534553 & 0.09 & 0.931 & -8.495247 & 9.279875 \\
\hline onlineserviceIndex & 2.718731 & 4.789495 & 0.57 & 0.570 & -6.668507 & 12.10597 \\
\hline HumanCapitalIndex & -7.702343 & 7.211698 & -1.07 & 0.286 & -21.83701 & 6.432326 \\
\hline TelecommunicationInfrastr e & 11.12754 & 4.277558 & 2.60 & 0.009 & 2.743679 & 19.5114 \\
\hline Lowermiddleincome & -6.735843 & 3.844149 & -1.75 & 0.080 & -14.27024 & .7985499 \\
\hline _cons & 40.23944 & 5.167374 & 7.79 & 0.000 & 30.11157 & 50.3673 \\
\hline sigma_u & 11.228809 & & & & & \\
\hline sigma_e & 1.5683937 & & & & & \\
\hline rho 0 & .98086398 & (fraction & var & $c e d u$ & u_i) & \\
\hline
\end{tabular}

The findings of hypothesis 3 regression indicate that e-government implementation and government effectiveness have positive effect on the perception of corruption. The regression results in Table 4 also show that the effectiveness of the government strengthens the positive influence between the adoption of e-government and the perception of corruption with greater
RSQUARE after moderation. This proves the role of governance is very strong. The public perception of corruption would increase with a more effective public service, civil service, degree of independence from political interference, development, execution of policies and legitimacy of government's commitment to policy.

Table 4. Result Hypothesis 3

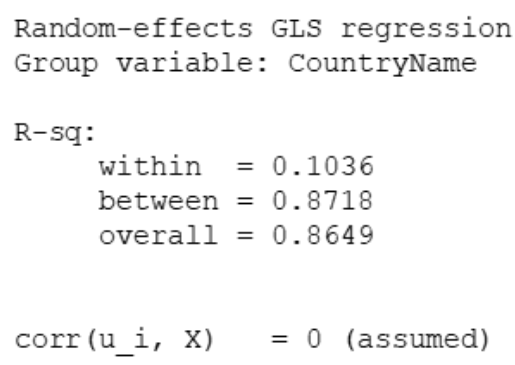

\begin{tabular}{r|rrrrrr}
\hline CPI & Coef. & Std. Err. & z & P $>|z|$ & [95\% Conf. Interval] \\
\hline EGovernmentIndex & 8.206811 & 3.482994 & 2.36 & 0.018 & 1.380268 & 15.03335 \\
GovernmentEffectiveness & 6.862649 & 2.143198 & 3.20 & 0.001 & 2.662059 & 11.06324 \\
egov_eff & 12.53132 & 3.408778 & 3.68 & 0.000 & 5.850242 & 19.2124 \\
Lowermiddleincome & 2.273425 & 2.0425 & 1.11 & 0.266 & -1.729801 & 6.276651 \\
_cons & 32.51692 & 2.573197 & 12.64 & 0.000 & 27.47354 & 37.56029 \\
\hline sigma_u & 5.6438959 & & & & \\
Sigma_e & 1.524857 & & & & \\
rho & .93196975 & (fraction of variance due to u_i)
\end{tabular}


Table 5 shows the regression results of the last hypothesis that telecommunications infrastructure and government effectiveness have a positive effect on perceptions of corruption. This means that the perception of corruption among people would be increased by more internet users, number of fixed telephone lines, cellular subscribers, wireless broadband subscriptions and broadband subscriptions. Moreover, the higher the quality of public services, civil service, degree of independence from political interference, policy formulation and implementation, and legitimacy of the government's commitment to policy would also improve the public perception of corruption. Meanwhile, the application of eparticipation, online service and human capital did not significantly influence the perception of corruption. Taking into account governance or government effectiveness as a moderating variable, the infrastructure component still contribute significant positive influence on corruption perceptions. The last RSQUARE is bigger than before. This means that the role of government effectiveness strengthens the influence of e-participation, online services, telecommunications infrastructure and human capital on corruption perceptions.

Table 5. Result Hypothesis 4

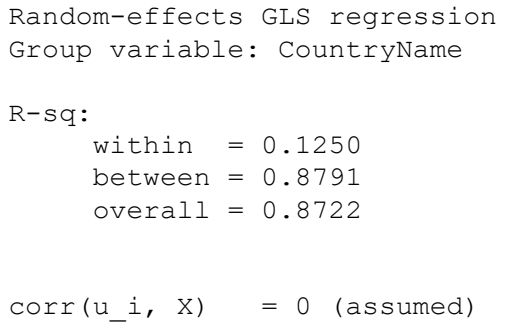

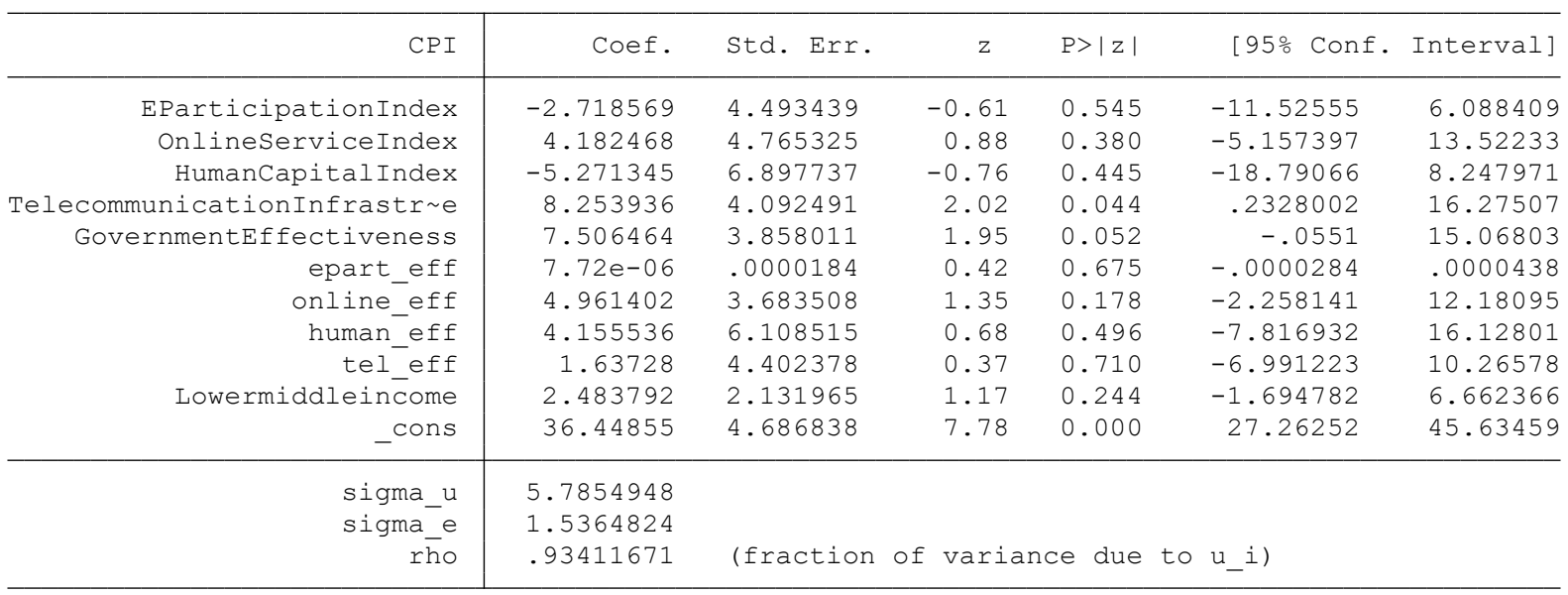

\section{Conclusion}

The conclusion of this research is the implementation of e-government and governance has increased the perception of corruption in countries in Asia. Of the several e-government components, only telecommunications infrastructure has a significant effect on perceptions of corruption. It is proven that telecommunication infrastructure in Asian developing countries has been well established and advanced. The commitment of the government to invest more in telecommunication has given benefits to the people including their perception of corruption which should be maintained. The results of this study also provide useful information to governments in Asia to further enhance the application of e-government through online services, human capital and e-participation. It gives recommendation for Asian govern- 
ments to make greater efforts that make information available online including public consultations, involve citizens directly involved online in decision-making process, increase literacy and education levels of their citizens and enhance the technical features of national websites (United Nation, 2018). The result of this paper also recommends the Asian government to increase its governance practices. More implementation of egovernment components and governance will have a significant impact on the perception of citizen corruption to governments in Asian countries. Besides these recommendations, this paper also has theoretical implication in elaborating information system theories especially related to e-government.

This paper has limitations in that it is done in a fairly short period of years, where egovernment indexes are published every 2 years. Therefore, the author suggests further research be made at a longer period. This study also only uses indicators of government effectiveness in measuring governance. Future studies can explore the use of other relevant governance indicators. Finally, future research can also add other control variables related to the implementation of e-government or government characteristics. Similar research can be developed into two things. First, focus on or explore the country level or comparison of several countries. Application of the country level, the survey indicators used in measuring the index of government development index can be applied. Second, expanding the population not only to Asian countries but to other continents to get a more comprehensive picture of the implementation of e-government as outlined by the United Nations. Lastly, using a questionnaire in exploring the use of e-government can also be examined.

\section{References}

Allen, A. (2001). E-Governance and government online in Canada: partnerships, people and prospects. Government Information Quarterly, 18(2), pp. 93-104.

Bertot, J. C. (2010). Using ICTs to create a culture of transparency. Government Information Quarterly, 27(3), pp. 264271.

Choi, H. (2016). Rethinking the assessment of e-government implementation in developing countries from the perspective of the design-reality gap. Telecommunications Policy, 40(7), pp. 644-660. https://doi.org/10.1016 /j.telpol.2016.03.002

Cordella, A. \& Paletti, A. (2017). Value creation, ICT, and co-production in public sector. Proceedings of the 18th Annual International Conference on Digital Government Research (pp. 185-194). New York : ACM https://doi.org/10.1145/3085228.3085 305

Geiller, L. (2019). Using government websites to enhance democratic Egovernance: A conceptual model for evaluation. Government Information Quarterly, 36(2), pp. 208-225

Krause, R. (2014). The administrative organization of sustainability within local government. Journal of Public Administration Research and Theory. 26(1), pp. 113-127.

Krishnan. (2013). Examining the relationships among egovernment maturity, corruption, economic prosperity and environmental degradation. Information and Management, pp. 638649. 
Lio, M. (2011). Can the internet reduce corruption? A cross-country study based on dynamic panel data models. Government Information Quarterly, 28(1), pp. 47-53. https://doi.org/10 $.1016 /$ j.giq.2010.01.005

Mates, P., Lechner, T., Rieger, P. \& Pěkná, J. (2013). Towards e-government project assessment: European approach. Zbornik Radova Ekonomskog Fakulteta u Rijeci, 31(1), pp. 103125. Retrieved from https://hrcak.srce .hr/104202

Nam, T. (2018). Examining the anticorruption effect of e-government. Government Information Quarterly, 35(2), pp. 273-282 https://doi.org /10.1016/j.giq.2018.01.005

Ndou, V. (2004). E - government for developing countries: Opportunities and challenges. The Electronic Journal on Information Systems in Developing Countries, 18(1), pp. 1-24.

Osman, I. H. (2014). COBRA framework to evaluate e-government services: A citizen-centric perspective. Government Information Quarterly, 31(2) pp. 243-256. https://doi.org/10.1016/j.giq .2013.10.009

Pina, V., Torres, L., \& Royo, S. (2007). Are ICTs improving transparency and accountability in the EU regional and local governments? an empirical study. Public Administration, 85(2), pp. 449472. https://doi.org/10.1111/j.14679299.2007.00654.x

Ryan, O. (n.d.). Reach integrating services to citizens - ppt download. SlidePlayer. Retrieved September 20, 2021, from https://slideplayer.com /slide/17562837/.
Saebo, O. (2008). The shape of eparticipation: Characterizing an emerging research area. Government Information Quarterly, 25(3), pp. 400428.

Satyanarayana, J. (n.d.). E-Government Principles. Retrieved from https://www.slideshare.net/frimentat eon/powerpoint-e-government.

Sobaci, Z, (2010). What the Turkish parliamentary web site offers to citizens in terms of e-participation: A content analysis. The Information Polity, 15(3), 227-241.

Srivastava, S. (2016). You can't bribe computer: Dealing with the societal challenge of corruption through ICT. MIS Quarterly, 40(2), pp. 511-526.

Starke, C. (2016). Free to expose corruption: The impact of media freedom, internet access and governmental online service delivery on corruption. International Journal of Communication, 10, pp. 4702-4722.

Susha, I., Zuiderwijk, A., Janssen, M., \& Grönlund, A. (2015). Benchmarks for evaluating the progress of open data adoption: usage, limitations, and lessons learned. Social Science Computer Review, 33(5), pp. 613630. https://doi.org/10.1177/0894439 314560852

Transparency International (2021). What is corruption? Retrieved from https://www.transparency.org/en/what -is-corruption

UAE Vision. (2021). Online service index. Retrieved from https://www.vision20 21.ae/en/national-agenda-2021/list /card/online-services-index 
UAE Vision. (2021). Telecommunication infrastructure index. Retrieved from https://www.vision2021.ae /en/national-agenda-2021/list/card /telecommunication-infrastructureindex-(tii)

United Nations. (2018). United Nations egovernment survey 2018: Gearing $e$ government to support transformation towards sustainable and Resilient Societies. New York: United Nation.

World Bank. (2019). Worldwide governance indicators. Retrieved from https://info.worldbank.org/governance /wgi/

World Bank. (2020). The human capital index 2020 update: Human capital in the time of COVID-19. Washington, DC: World Bank.

Yildiz, M. (2007). E-government research: Reviewing the literature, limitations, and ways forward. Government Information Quarterly, 24(3), pp. 646665 . https://doi.org/10.1016/j.giq .2007 .01 .002 